
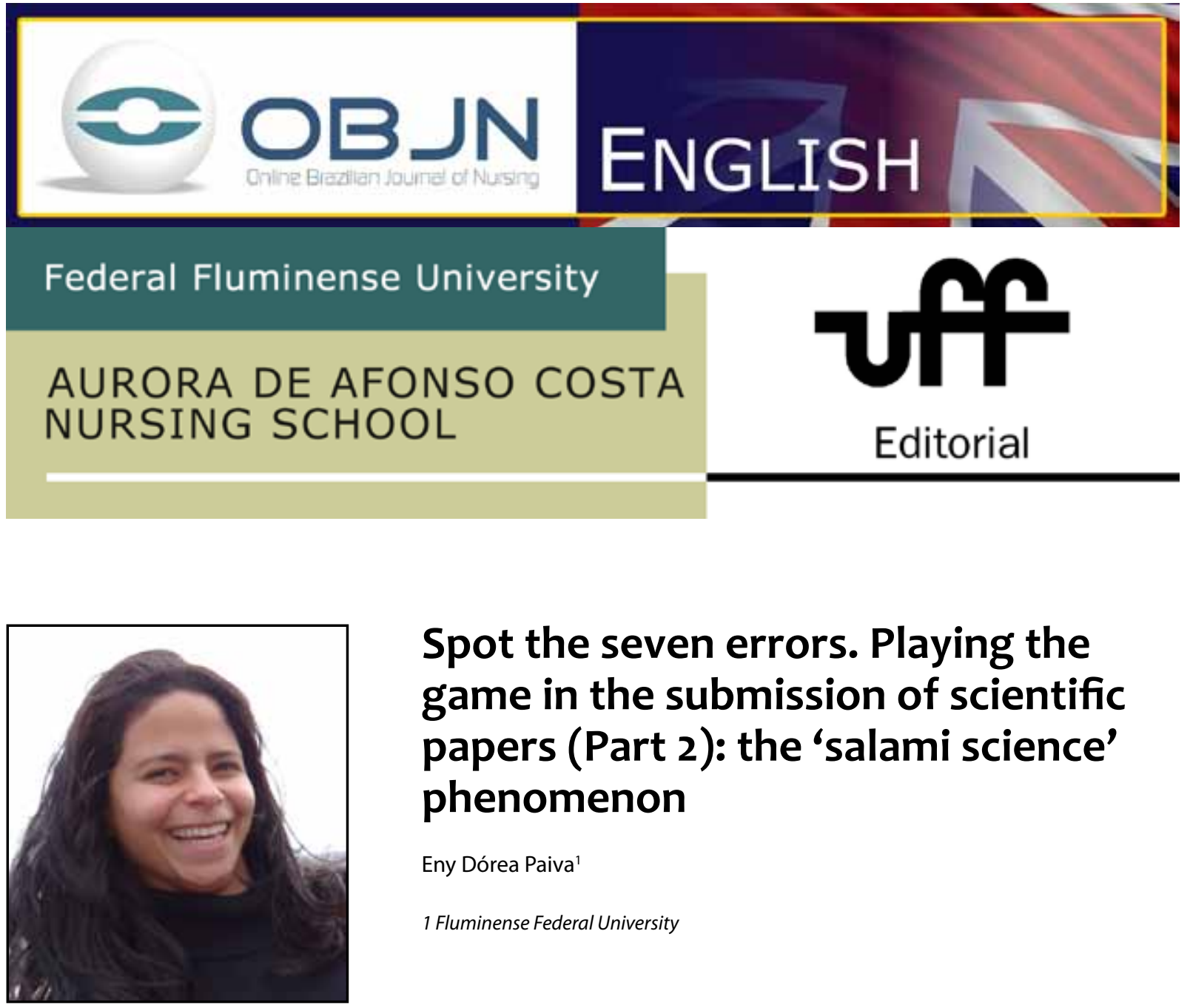

\title{
Spot the seven errors. Playing the game in the submission of scientific papers (Part 2): the 'salami science' phenomenon
}

Eny Dórea Paiva'

1 Fluminense Federal University

\begin{abstract}
Continuing "Spot the seven errors" game in the submission of scientific papers process begun in the previous issue, this editorial will discuss a second error: the 'salami science' phenomenon. For the trajectory of professionals working in the academic world is essential to undertake studies and subsequent publication of his findings. In this context, the 'salami science' is to publish results of a single study in several scientific articles, resulting in jobs with low relevance and little originality. It is observed that there is already a tendency to avoid the practice of this phenomenon. These actions will ensure the credibility of the journals, increasing the dissemination of appropriate conduct in the submission of scientific articles.
\end{abstract}

Descriptors: Access to Information; Duplicate Publication; Scientific misconduct, Scientific Publication Ethics.

Spot the seven errors. Playing the game in the submission of scientific papers (Part 2): the 'salami science' phenomenon [editorial]. Online Braz j nurs 2014; 13(2). 
Continuing the "Spot the seven errors" game in the submission of scientific papers process begun in the previous issue, this editorial discusses a second error: the 'salami science' phenomenon. It is important to confirm and clarify that the comments in future editorials on this subject are not prioritized regarding their importance or chronologic link; however, they should not be overlooked ${ }^{(1)}$.

For the path of professionals working in the academic area it is essential to undertake studies and subsequent publication of his findings. These studies must have fundamental characteristics, such as creativity, originality and relevance of the topic in the discussed area.

In the current paradigm of evaluating postgraduate researchers and their programs, the publication of these papers is seen as a "ghost haunting" the lives of all those linked to the academic realm. In this context, there is the concern of researchers in relation to the quantity of publications rather than the quality of them ${ }^{(2)}$.

The 'salami science' phenomenon consists in publishing the results of a single study in several scientific articles. This phenomenon becomes a problem because it wastes valuable and limited resources. For the journals, it's a waste of paper; for reviewers, a waste of time, which could be used to assess the studies that present new data; and, for readers, it also wastes time which could be spent on reading new research $\operatorname{articles}^{(3)}$.

Some authors attribute the motivation of researchers in "slicing" their findings to three possible reasons. First, many researchers, especially in the academic world, face the pressure of publicating their work. Secondly, institutions judge the potential success of candidates by the number of their publications and not necessarily the merits of the them. And, thirdly, there are the financial interests of pharmaceutical companies, which aims to fund and disseminate a new drug, seeking support in the literature ${ }^{(3)}$.

The result for "slicing" a single research project in various publications is that most studies have low relevance and little originality. It, also, ends to encouraging unethical practices by researchers, such as self-citation or citation between friends as a way to artificially raise the impact factor of publications - as they are not 'naturally' in sufficiency cited in the literature by other scientists ${ }^{(4)}$.

The guide for best practices related to ethical guidelines states that for best publication of a manuscript the integrity in research, writing and peer review should be encouraged, to set a gold standard for editorial processes. The purpose of these guidelines is to assist all those involved in academic publishing, presenting a guidance summary of best practice from leading organizations all over the world. Thus, the directives in this guide are aimed to companies, publishers, authors, librarians, students, funders, businesses and journalists ${ }^{(2,5)}$.

It is known that there are barriers to the publication and dissemination of scientific knowledge, which must be overcome through the sharing of experiences and strengthening of ties between countries. These barriers are related to language, techniques and methodologies, to article formatting, to the access to research results as consumers and as producers, and to the costs of production and dissemination of scientific knowledge ${ }^{(6)}$.

The Coordination of Improvement of $\mathrm{Hi}$ gher Education Personnel Institution (Capes, in Portuguese) plays a key role in the expansion and consolidation of the strictu sensu graduate programs (master and doctorate) in all states of the Federation. Among other activities, there is a structured program for access and dissemination of scientific production ${ }^{(7)}$ together. Qualis is the set of procedures used by CAPES for stratifying 
the quality of intellectual output of postgraduate programs. As a result, it provides a list of rankings of journals used by these programs for the dissemination of its production. Thus, Qualis measures the quality of articles and other types of production, through the analysis of the quality of dissemination vehicles, i.e., the journals ${ }^{(8)}$. Despite the encouragement for researchers by the amount of publications of manuscripts, we observe that the articles should be published taking into account the quality of journals.

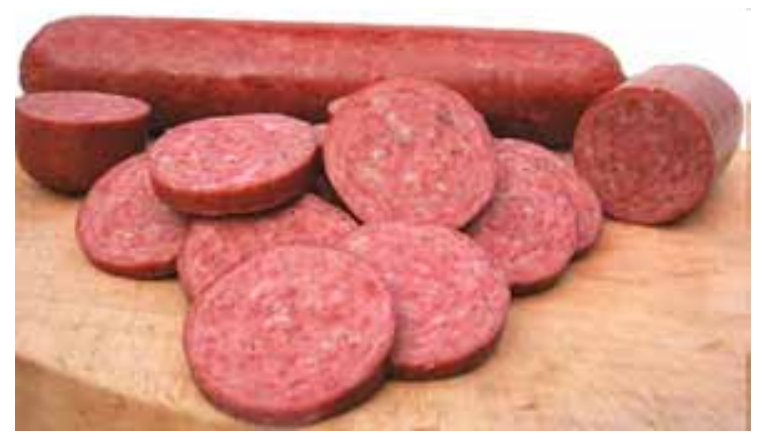

On the other hand, as important as the quality of the magazines is the quality of the manuscripts. Two sets of problems that compromise the overall quality of scientific publications were identified: the science quality and its presentation; and misconduct in the scientific research. Thus, the problems range from the scientific reproducibility to the ones associated with the quality of textual production, in addition to fraud and plagiarism in publication ${ }^{(9)}$. Regarding the quality of the written material, some works are rejected by the magazines due to vague and too general introductions, objectives unconnected with the results and conclusions, confusing and inadequate methods, results not discussed properly and errors of spelling and grammar ${ }^{(10)}$.

As an example of the absurd the 'salami science' behavior can produce, there is a survey conducted by Professor Sidney Redner of Boston University on publications of one of the journals in his area, the Physical Review. The numbers obtained are scary: of the 353,000 published articles, only 11 were cited more than 1,000 times; 245,000 (the biggest part) were cited less than 10 times; 100,000 were cited once or not at all. Thus, it can be seen that $1 / 3$ of the publications of this journal has no impact. And despite the absence of other similar studies, there is speculation that for most magazines there is this similar behavior ${ }^{(11)}$.

Given the above, what can we do to prevent the 'salami science' phenomenon? It is observed that there is already a tendency to stop the practice of duplicate publications or articles from the same research, and authors should be aware of these problems in order to avoid them. Editors need to ensure the quality of their scientific journals through the publication of quality and original material. Finally, the reviewers at the time of analyzing the manuscripts and preparing their opinions, should pay attention to the existence of any fraud, plagiarism and/or self-plagiarism. Thus, these actions will enhance the credibility of the journals, increasing the dissemination of appropriate conduct in the submission of scientific articles.

\section{REFERENCES}

1. Lima DVM. Spot the seven errors. Playing the game in the submission of scientific papers (Part 1): the horse and the carrot [editorial] [internet]. Online braz j nurs 2014. [cited 2014 Jun 09]; 13(1):1-4. Available from: http://www.objnursing. uff.br/index.php/nursing/article/view/4635

2. Deakin L et al. Best Practice Guidelines on Publishing Ethics: a Publisher's Perspective. 2014; [cited Jun 09 2014]. Available from: http://exchanges.wiley.com/medialibrary/2014/03/17/ 8440af20/Best\%20Practice\%20Guidelines $\% 20$ on\%20Publishing\%20Ethics\%202ed.pdf

3. Elstein AS, Cadmus C, Pitkin R, Mundy D, McDowell C. Salami Science: Are We Still Allowing It?. CBE VIEWS 1998. [cited Jun 09 2014]; 21(6): 200. 
Available from: http://www.councilscienceeditors.org/wp-content/uploads/v21n6p200.pdf

4. Escobar H. [homepage]. Cientistas pedem menos quantidade e mais qualidade nas avaliações. [cited Jun 102014 ]. Available from: http:// blogs.estadao.com.br/herton-escobar/cientistas-pedem-menos-quantidade-e-mais-qualidade-nas-avaliacoes/

5. Conselho Nacional de Saúde (Brasil). Resolução $\mathrm{n}^{\circ}$. 466, de 12 de dezembro de 2012. Diretrizes e normas regulamentadoras de pesquisas envolvendo seres humanos. Diário Oficial da União Poder Executivo 13 jun 2013; seção 1.

6. Lima DVM. Equalization and free access to information: basis for the effective iberian-american cooperation. Online braz j nurs [Internet]. 2011 April [Cited 2014 Jun 09]; 10 (1): Available from: http://www.objnursing.uff.br/index.php/nursing/article/view/3223

7. CAPES [homepage]. Sobre a Capes. [cited Jun 10 2014]. http://www.capes.gov.br/sobre-a-capes/ historia-e-missao

8. CAPES [homepage]. Notícias. [cited Jun 102014$].$ http://www.capes.gov.br/36-noticias/6439-atualizacao-final-do-qualis-periodicos-para-a-avaliacao-trienal-2013

9. Carver JD, Dellva B, Emmanuel PJ, Parchure R. Ethical considerations in scientific writing. Indian J Sex Transm Dis. 2011 Jul-Dec; 32(2): 124-128.

10. Albuquerque UP. A qualidade das produções científicas - considerações de um Editor de Área ao final do mandato. Acta bot. Bras. 2009;23(1):292-296

11. Slobodian V. [homepage]. Polegar Opositor: Salami Science, autoria contestável e o alpinismo científico. [cited Jun 102014 ]. Available from: http://polegaropositor.com.br/filosofiadacien cia/\%E2\%80\%9Csalami-science\%E2\%80\%9D-autoria-contestavel-e-o-alpinismo-cientifico/
Imagem: https://encrypted-tbn1.gstatic.com/ images?q=tbn:ANd9GcTjEa-f55vCQZnniUk3Jn_TGXR2TvF7CaoL6zH_JUxSvk7S6K9dA

All authors participated in the phases of this publication in one or more of the following steps, in According to the recommendations of the International Committee of Medical Journal Editors (ICMJE, 2013): (a) substantial involvement in the planning or preparation of the manuscript or in the collection, analysis or interpretation of data; (b) preparation of the manuscript or conducting critical revision of intellectual content; (c) approval of the versión submitted of this manuscript. All authors declare for the appropriate purposes that the responsibilities related to all aspects of the manuscript submitted to OBJN are yours. They ensure that issues related to the accuracy or integrity of any part of the article were properly investigated and resolved. Therefore, they exempt the OBJN of any participation whatsoever in any imbroglios concerning the content under consideration. All authors declare that they have no conflict of interest of financial or personal nature concerning this manuscript which may influence the writing and/or interpretation of the findings. This statement has been digitally signed by all authors as recommended by the ICMJE, whose model is available in http://www. objnursing.uff.br/normas/DUDE_eng_13-06-2013.pdf

Received: 04/08/2014
Revised: 04/08/2014
Approved: 04/09/2014 